\title{
APLIKASI PENGELOMPOKAN PELANGGAN PADA UMS STORE MENGGUNAKAN ALGORITMA K-MEANS
}

\author{
Muhammad Abdul Ghofar ${ }^{1)}$, Yogiek Indra Kurniawan ${ }^{2)}$ \\ ${ }^{1)}{ }^{2)}$ Program Studi Informatika, Fakultas Komunikasi dan Informatika \\ Universitas Muhammadiyah Surakarta \\ mvghofar1@gmail.com ${ }^{1)}$,yogiek@ums.ac.id ${ }^{2)}$
}

\begin{abstract}
UMS Store is an official trading business unit owned by Muhammadiyah University of Surakarta that provides various categories of books, journals, office stationery and official marchandise. UMS Store is also a voucher exchange center for students. Of the many voucher redemption transactions and cash purchases, UMS Store has abundant data and will continue to grow over time. The abundant data if left unchecked would be a pile of only stored data. Actually, if the data is excavated will produce valuable information. UMS Store need a customer grouping application that will be used to provide continuous treatment such as giving discounts or vouchers to their best customers. This research is done to create the application, where application can make customer grouping with UMS Store data and can give recommendation through potential group that formed. This application was developed by utilizing $K$ means algorithm, which is one of clustering method in data mining technique. Groupings made in the application are limited to 3 large groups of data with restrictions using only student data using UMS Store vouchers. Variables used consist of NIM, year force, discount, sub total, total paid, total item and date. The results of this study is an application used to classify customers using $K$-means method. The results of this study indicate that if the application is used to create three groups, it will form three clusters, ie clusters of potential customers, normal customers and unlikely customer clusters.
\end{abstract}

\section{Keywords: Clustering, Data Mining, K-Means, UMS Store}

\section{PENDAHULUAN}

UMS Store merupakan sebuah unit usaha dagang resmi yang dimiliki oleh Universitas Muhammadiyah Surakarta. Selain menyediakan berbagai macam kategori buku, tersedia pula jurnal, alat tulis kantor serta official merchandise berupa barang yang mencirikan UMS. UMS Store juga menjadi pusat layanan program penukaran voucher bagi mahasiswa aktif yang diselenggarakan Universitas Muhammadiyah Surakarta. Voucher tersebut diberikan kepada mahasiswa setiap semesternya dari semester satu hingga tujuh.

Teknologi yang berkembang pesat membuat kita hidup didunia yang penuh dengan data. Setiap hari, sistem dapat mengumpulkan data dalam jumlah besar dari transaksi pelanggan (Khandre \& Alvi, 2016). Sejak awal berdirinya UMS Store telah melakukan banyak proses transaksi, baik penukaran voucher maupun pembelian tunai. Dengan kata lain UMS Store memiliki data yang amat berlimpah dan pasti akan terus bertambah seiring berjalannya waktu. Banyaknya data yang tersimpan tersebut membuat pengklasifikasian data menjadi lebih sulit dan rumit, khususnya dalam hal kepentingan organisasi. Selain itu proses pengelompokan data tersebut juga tidak mungkin dilakukan, mengingat keterbatasan kemampuan yang dimiliki manusia pada bila menggunakan cara manual (Nugroho \& Haryati, 2015).

Banyak sekali perusahaan yang tidak menyadari bahwa tumpukan data yang selama ini hanya disimpan sebenarnya sangat berharga. Bahkan banyak diantara data tersebut hanya dipandang sebagai arsip semata dan kemudian menjadi data tak terpakai yang akhirnya dibuang. Dengan penanganan yang tepat, apabila data tersebut diproses maka akan diperoleh informasi strategis yang berguna bagi masa depan perusahaan. Salah satu solusi yang dapat digunakan untuk mengatasi masalah ini ialah dengan menggunakan data mining dengan teknik klastering atau pengelompokan. Data mining dapat digunakan sebagai alternatif dalam pengolahan data menjadi sumber informasi strategis yang dapat pula sebagai pendukung pengambilan keputusan suatu perusahaan dimasa mendatang. 
Data mining merupakan sekumpulan proses yang dilakukan dalam menemukan dan menggali nilai tambah dari sekumpulan data yang selama ini sulit diketahui secara manual. Kata mining dalam pengertiannya berarti usaha untuk mendapatkan sedikit pengetahuan berharga dari sejumlah besar material dasar. Dengan demikian data mining yang diterapkan memiliki tujuan yaitu untuk mengungkap dan menggali pola tersembunyi dari sejumah data. Proses data mining sangat diperlukan, terutama untuk mengolah data dalam jumlah yang besar demi memberikan informasi strategis yang akurat (Bahar, Pramono, \& Sagala, 2016). Data mining dilakukan untuk mengekstrak informasi berharga dari sebuah dataset dan kemudian memaparkannya dalam format yang mudah dimengerti oleh manusia dengan tujuan untuk mengambil sebuah keputusan (Ezenkwu, Ozuomba, \& Kalu, 2015)

Dalam penelitian sebelumnya Sumadikarta, dkk (2016) mengembangkan sebuah aplikasi dengan konsep data mining menggunakan algoritma $k$-means yang berfungsi untuk mengelompokkan data pelanggan serta data produk pada PT Mega Arvia Utama. Hasil dari sistem ini adalah membentuk klaster yang digunakan sebagai bahan pertimbangan dalam menentukan strategi penjualan perusahaan yaitu, dengan menghilangkan produk yang menempati klaster terbawah dan memeberikan reward kepada pelanggan poternsial yang menempati klaster teratas. Bahar, dkk (2016) juga mengembangkan sistem penentuan strategi yang dibuat untuk menerapkan metode data mining dengan menggunakan algoritma K-Means Clustering, yaitu dengan cara melakukan pembagian data yang ada menjadi satu atau lebih cluster. Tujuan dari penelitian tersebut adalah untuk membagi data ke dalam beberapa kelompok, berfokus pada produk yang paling diminati.

Tikmani, dkk (2015) melakukan penelitian untuk mengelompokkan pelanggan dan bagaimana algoritma $k$ means dapat digunakan untuk membagi pelanggan kedalam kelompok yang berbeda. Penelitian ini menggambarkan mengenai segmentasi pelanggan dan menjelaskan algoritma clustering secara rinci. Secara khusus juga menggambarkan penggunaan teknik $k$-means clustering dan menjelaskan penggunaanya dalam segmentasi pelanggan perusahaan televisi berdasarkan berbagai variabel. Hasil simulasi menunjukkan pembagian delapan puluh pelanggan televisi ke dalam empat kelompok. Pada penelitian serupa, Lanjewar, dkk (2013) menguraikan teknik pengelompokan data untuk melakukan segmentasi pelanggan pada perusahaan produk susu. Proses klastering dapat membantu untuk mengidentifikasi kebutuhan dan perilaku pelanggan dan meningkatkan layanan demi kepuasan pelanggan. Dalam industri apapun langkah pertama untuk menemukan dan menghasilkan pelanggan yang menguntungkan ialah dengan pengelompokan. Hasil dari sistem tersebut memberikan profil dan pemahaman yang lebih baik terhadap pelanggan. Dalam penelitian serupa, Jain, dkk (2014) mengelompokkan konsumen berdasarkan perilaku belanja konsumen. Data yang dikumpulkan dari 1014 responden dilakukan pengelompokan dengan metode $k$ means dan menghasilakn empat buah kelompok pelanggan. Mengelompokkan pelanggan kedalam segmen tertentu dapat membantu pemasaran dalam penargetan konsumen dengan lebih terfokus.

Berdasarkan latar belakang tersebut, maka penelitian ini akan mengembangkan sebuah aplikasi klastering dengan teknik data mining menggunakan algoritma $K$-means. Aplikasi ini dibuat untuk melakukan pengelompokan pelanggan pada UMS Store untuk menemukan kelompok pelanggan potensial, yang nantinya akan digunakan untuk memberikan rekomendasi berupa treatment dan penanganan lebih lanjut.

\section{METODOLOGI}

Bab ini menjelaskan berbagai tahapan yang dilakukan dalam melakukan penelitian, sehingga dapat sesuai dengan tujuan penelitian. Adapun alur tahapan dalam metodologi penelitian ini ditunjukkan pada Gambar 1. 


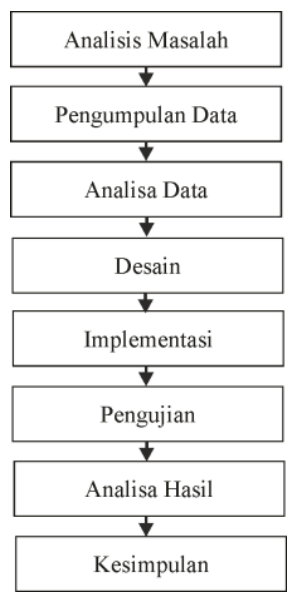

Gambar 1. Tahapan metodologi penelitian

\subsection{Analisis Masalah}

Banyaknya transaksi pelanggan pada UMS Store menjadikan data yang dimiliki semakin berlimpah setiap harinya. Data yang berlimpah ini apabila dibiarkan akan menjadi tumpukan data yang tersimpan saja. Sebenarnya data tersebut apabila digali akan memberikan informasi yang berharga. Sehingga perlu dikembangkan sebuah Aplikasi yang dapat digunakan untuk melakukan pengelompokan data di UMS Store. Penelitian ini dilakukan dengan tujuan melakukan pengelompokkan pelanggan potensial yang diambil dari data transaksi UMS Store. Obyek penelitian ini dipilih karena transaksi pelanggan didominasi oleh mahasiswa UMS. Hasil dari penelitian ini digunakan untuk memberikan rekomendasi pada UMS Store terhadap pelanggan potensial yang ada. Berdasarkan rekomendasi tersebut, UMS Store dapat memeberikan penanganan lebih lanjut pada kelompok potensial yang terbentuk berupa perlakuan istimewa atau treatment belanja seperti memberikan diskon untuk pembelian selanjutnya. Hal ini nantinya akan menambah minat mahasiswa untuk berbelanja di UMS Store. Pengelompokan pada penelitian ini dibatasi pada data transaksi mahasiswa dengan pembelian menggunakan voucher UMS Store saja, sehingga proses pengklasteran dapat lebih spesifik.

\subsection{Pengumpulan Data}

Pengumpulan data dilakukan untuk memperoleh informasi serta data yang dibutuhkan agar dapat mencapai tujuan akhir penelitian. Pengumpulan data memiliki tujuan mendapatkan data akurat yang akan digunakan dalam penelitian guna menentukan hasil akhir yang baik (Kurniawan \& Windisani, 2017). Data yang digunakan dalam penelitian ini diperoleh dari pihak UMS Store sesuai kebutuhan data penelitian ini.

\subsection{Analisa Data}

Tahap ini dilakukan untuk menentukan kebutuhan data dalam pengembangan aplikasi. Total keseluruhan data yang diperoleh dari UMS Store sebanyak 9031 data. Data yang akan digunakan dibatasi dengan hanya mengambil data pelanggan yang berstatus mahasiswa dan menggunakan voucher saja dibulan Mei 2017, sehingga diperoleh sampel data akhir sejumlah 357 untuk dilakukan pengelompokan. Pembersihan data juga dilakukan agar data sesuai dengan kebutuhan aplikasi, sehingga data nantinya tidak memiliki noise atau ketidakkonsistenan saat pengujian dilakukan.

Variabel yang digunakan dalam proses pengelompokan ini dipilih berdasarkan tujuan penelitian seperti yang tertera pada tabel 1 .

Tabel 1. Daftar variabel yang digunakan

\begin{tabular}{|c|c|c|}
\hline $\begin{array}{c}\text { Nama } \\
\text { Variabel }\end{array}$ & $\begin{array}{l}\text { Tipe } \\
\text { Data }\end{array}$ & Deskripsi \\
\hline NIM & Nominal & Kode mahasiswa \\
\hline $\begin{array}{l}\text { Tahun } \\
\text { Angkatan }\end{array}$ & Numeric & $\begin{array}{l}\text { Tahun angkatan } \\
\text { mahasiswa }\end{array}$ \\
\hline Discount & Numeric & $\begin{array}{l}\text { Total diskon yang } \\
\text { diperoleh }\end{array}$ \\
\hline Subtotal & Numeric & Total harga keseluruhan \\
\hline $\begin{array}{l}\text { Total } \\
\text { Paid }\end{array}$ & Numeric & $\begin{array}{l}\text { Total harga yang harus } \\
\text { dibayarkan setelah } \\
\text { dipotong diskon }\end{array}$ \\
\hline Total Item & Numeric & $\begin{array}{l}\text { Jumlah barang yang } \\
\text { dibeli }\end{array}$ \\
\hline Tanggal & Date & $\begin{array}{l}\text { Tanggal transaksi } \\
\text { pembelian }\end{array}$ \\
\hline
\end{tabular}

\subsection{Desain}

Pada tahap desain, dilakukan perancangan dari aplikasi yang akan dibangun. Perancangan menggunakan metode Unified Modeling Language (UML) dengan diagram usecase. Diagram usecase menggambarkan interaksi yang dapat dilakukan oleh pengguna di dalam aplikasi (Lihat pada Gambar 2). 


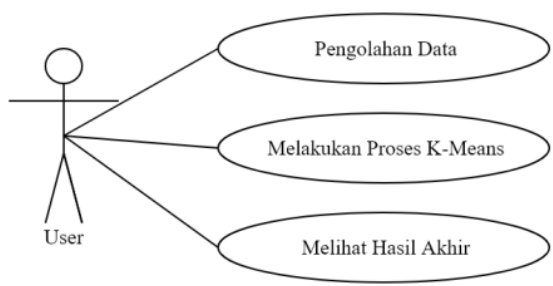

Gambar 2. Usecase diagram aplikasi

Pada Gambar 2, terdapat sebuah aktor yang berperan didalam aplikasi yaitu user atau pengguna aplikasi. Interaksi yang dapat dilakukan pengguna dalam aplikasi yang pertama adalah pengolahan data, sebagai contoh pengguna dapat menambah, mengubah, menghapus data, dan melakukan upload data dalam bentuk sebuah file csv. Selanjutnya pengguna dapat melakukan proses pengelompokan K-means dengan menjalankan fungsi proses. Selain itu pengguna juga dapat melihat hasil akhir dari proses pengelompokan. Aplikasi pengelompokan ini dibuat menggunakan database Mysql dan bahasa pemrograman PHP dan Mysqli untuk melakukan perancangan antarmuka aplikasi.

\subsection{Implementasi}

Salah satu algoritma yang dapat menyelesaikan permasalahan dalam melakukan pengklasteran adalah dengan menggunakan algorima $K$-means. Huruf k pada $k$ means mewakili jumlah kelompok yang dipilih. Dalam algoritma $k$-means setiap kumpulan data diperlakukan sebagai objek yang memiliki beberapa lokasi. K-means menemukan partisi sehingga objek di dalam kelompok cluster sangat dekat satu sama lain, dan sangat jauh dan berebeda dengan kelompok lain. (Tikmani, Tiwari, \& Khedkar, 2015). K-means menggunakan pendekatan iteratif untuk meminimalkan jumlah jarak antara setiap objek dengan centroid. K-means digunakan secara luas untuk melakukan analisis data dengan volume besar yang dihasilkan oleh berbagai sistem modern (Khandre \& Alvi, 2016)

Berikut langkah pada algoritma $k$-means:

1. Menentukan nomor cluster (jumlah Kelompok)

2. Menentukan nilai centroid awal pada setiap klaster (dipilih secara acak)
3. Ulangi langkah berikut sampai anggota tidak berubah, dimana tidak ada data pada setiap cluster yang dapat berpindah ke cluster lain:

a. Tentukan nilai untuk centroid baru

b. Hitung jarak diatara setiap data dengan centroid

c. Kelompokkan data berdasarkan jarak terdekat dengan centroid

Flowchart dari algritma $k$-means tersebut dapat dilihat melalui Gambar 3.

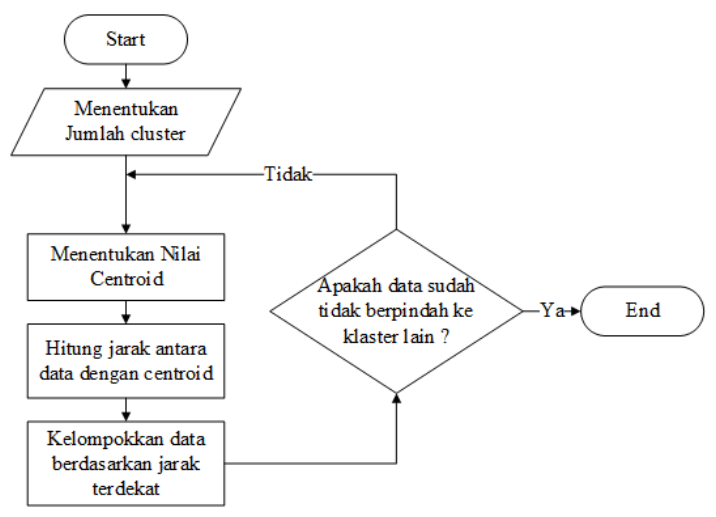

Gambar 3. Flowchart algoritma k-means

$K$-means dapat membagi data menjadi beberapa kelompok, sehingga data yang mempunyai kesamaan karakteristik akan dikelompokkan dalam satu cluster, sedangkan data yang berbeda karakteristiknya dikelompokkan pada cluster lain. Dalam membagi kelompok tersebut digunakan persamaan Euclidean distance space (persamaan 1) yang digunakan untuk menghitung jarak terpendek antara dua titik yang diperhitungkan yaitu data dengan centroid (Nugroho \& Haryati, 2015).

$$
d_{i j}=\sqrt{\sum_{k=1}^{p}\left(x_{i k}-x_{j k}\right)^{2}}
$$

Keterangan:

$d_{i j} \quad:$ Euclidean distance, Jarak antara objek i dan j

p : Dimensi data yang digunakan

$x_{i k} \quad:$ Koordinat data ke-i

$x_{j k} \quad:$ Koordinat centroid ke-j 
Sedangkan untuk memperoleh titik centroid baru dilakukan dengan cara menghitung nilai rata-rata dari data yang ada pada cluster yang sama menggunakan persamaan 2 .

$$
C_{k}=\frac{1}{n_{k}} \sum d_{i}
$$

\section{Dimana:}

$n_{k}:$ Jumlah data dalam cluster

$d_{i}$ : Jumlah nilai jarak yang masuk dalam setiap cluster

\subsection{Pengujian}

Setelah aplikasi pengelompokan pelanggan selesai dibuat, tahapan selanjutnya adalah pengujian. Pengujian ini memiliki tujuan untuk mengetahui apakah aplikasi sudah berjalan dengan baik sesuai dengan penelitian. Pengujian dengan metode blackbox dilakukan terhadap aplikasi pengelompokan untuk mengetahui apakah telah berfungsi dengan baik ataukah belum. Pengujian tersebut memiliki tujuan dalam menemukan fungsi yang gagal atau hilang, kesalahan struktur data, interface dan akses database (Prabiantissa, Ririd, \& Asmara, 2017). Pengujian terhadap hasil pengelompokan juga dilakukan untuk membuktikan kebenaran hasil pengelompokan yang telah dilakukan sebelumnya (Handoko, 2016). Metode pengujian terhadap hasil pengelompokan dilakukan dengan cara membandingkan hasil yang pengelompokan aplikasi dengan hasil pada software RapidMiner.

\subsection{Analisis Hasil}

Pada penelitian ini, aplikasi pengelompokan pelanggan dengan menggunakan algoritma K-means setelah diterapkan pada data UMS Store akan menghasilkan tiga buah cluster. Berdasarkan hasil dari pengelompokan ini akan diketahui anggota kelompok manakah yang menjadi rekomendasi pelanggan potensial yang nantinya akan mendapatkan treatment lebih lanjut oleh UMS Store. Dilihat dari hubungan dengan pelanggan pengelompokan ini dapat menentukan pelanggan potensial yang dimiliki oleh UMS Store, sehingga apabila ada suatu event atau diskon dapat melibatkan pelanggan tersebut. Dilihat dari segi sistem, aplikasi ini memudahkan UMS Store dalam menentukan pelanggan potensial tanpa memerlukan tenaga tambahan dalam melakukan analisa.

\subsection{Kesimpulan}

Pada tahap ini, penulis merumuskan suatu kesimpulan sesuai dengan penelitian dan hasil yang telah dilakukan dalam pembuatan tugas akhir ini.

\section{HASIL DAN PEMBAHASAN}

\subsection{Implementasi Hasil}

Aplikasi pengelompokan pelanggan pada UMS Store telah selesai diimplementasikan. Aplikasi ini terdiri atas beberapa halaman. Halaman utama merupakan tampilan awal dimana pengguna telah memasuki aplikasi, halaman ini berisi sedikit penjelasan mengenai aplikasi pengelompokan. Terdapat beberapa menu yang dapat diakses pengguna antara lain menu Home, Project dan About.

Gambar 4 menunjukkan Menu Project, menu ini merupakan menu yang berperan dalam melakukan proses utama pada pengelompokan. Pada menu ini pengguna dapat melihat tampilan data yang akan diproses serta melakukan pengolahan data seperti edit dan hapus data.Terdapat beberapa button untuk melakukan proses lain diantaranya input data, upload data dan proses $K$ means.

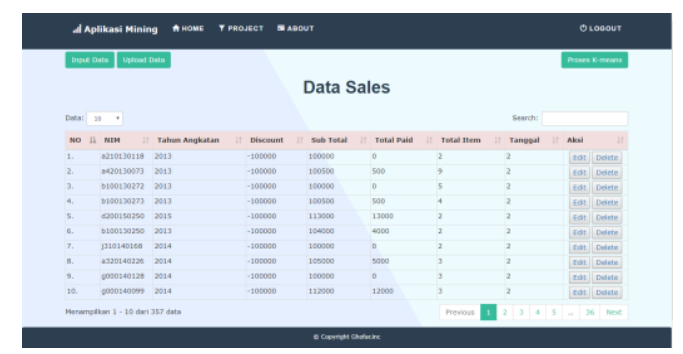

Gambar 4. Tampilan menu Project

Button Input data yang berada pada bagian kiri memiliki fungsi untuk menambah data. Dan apabila dijalankan maka akan ditampilkan sebuah form yang digunakan untuk pengisian data yang akan ditambahkan, seperti pada Gambar 5. Data tersebut akan disimpan kedalam database. 


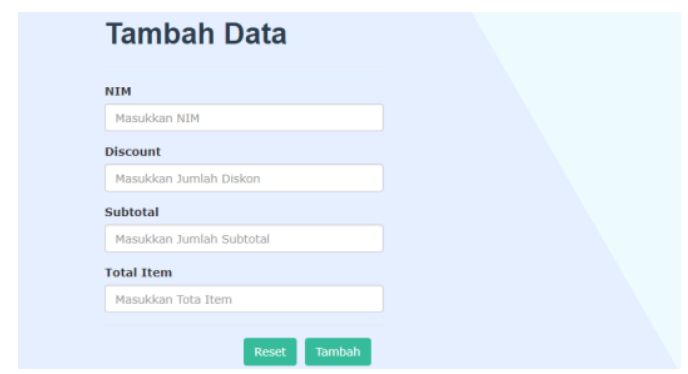

Gambar 5. Tampilan form pengisian data

Untuk mengupolad data yang berasal dari file csv, pengguna dapat menjalankan button upload data yang apabila dijalankan nantinya akan menampilkan sebuah form untuk memilih file dari komputer pengguna seperti pada Gambar 6.

\section{Import File CSV: \\ Choose Files No file chosen \\ (๑) UPLOAD}

\section{Gambar 6. Tampilan upload data CSV}

Pada bagian kanan menu Project terdapat button Proses Data yang digunakan untuk melakukan inisialisasi proses. Apabila button dijalankan maka akan tampil sebuah form, dimana pengguna diminta untuk memasukkan jumlah cluster dan jumlah maksimal iterasi yang akan diproses pada form tersebut. Gambar 7 menunjukkan tampilan hasil centroid yang diambil dari data secara acak. Kemudian centroid berikutnya diperoleh dari perhitungan nilai rata-rata dengan menggunakan persamaan yang telah dibahas pada bab 2 .

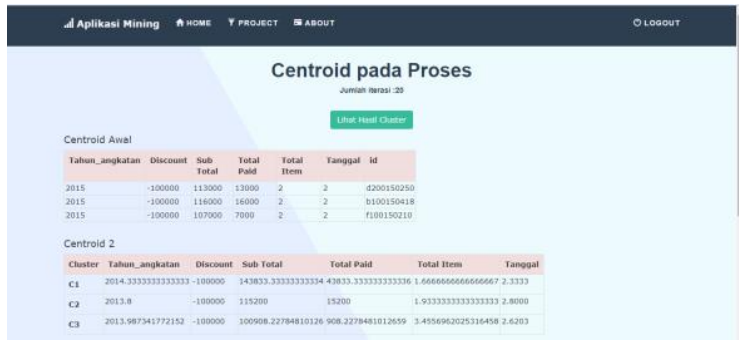

Gambar 7. Tampilan Centroid pada proses

Kemudian untuk dapat melihat hasil akhir pengelompokan tersebut, terdapat button Lihat Hasil Cluster. Pengguna akan diarahkan menuju halaman Hasil Cluster seperti yang ditunjukkan pada Gambar 8.
Halaman ini menampilkan tabel berisi keterangan anggota kelompok beserta hasil cluster.

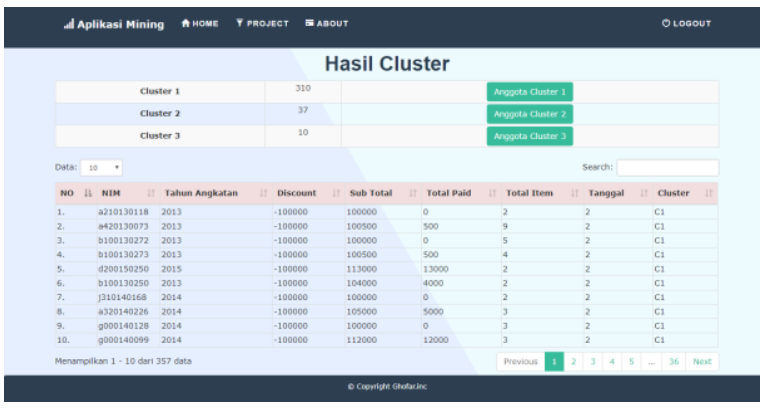

Gambar 8. Tampilan hasil cluster

Berdasarkan Gambar 8, untuk dapat melihat anggota dari setiap cluster tersedia button yang akan menampilkan tabel sesuai dengan cluster yang dipilih. Pembahasan

\subsection{Pembahasan}

Berdasarkan hasil penelitian yang telah dilakukan, dapat diperoleh proses perhitungan menggunakan algoritma $k$ means. Perhitungan ini sesuai dengan langkah -langkah pada algoritma k-means yang telah dijelaskan sebelumnya. Pertama ialah menentukan nilai centroid awal yang diambil dari data secara random atau acak. Daftar centroid awal yang telah diproses dapat dilihat pada tabel 2

Tabel 2. Daftar centroid awal

\begin{tabular}{|c|c|c|c|c|c|c|}
\hline K & \multicolumn{5}{|c|}{ Centroid } \\
\hline A & 2015 & -100000 & 113000 & 13000 & 2 & 2 \\
\hline B & 2015 & -100000 & 116000 & 16000 & 2 & 2 \\
\hline C & 2015 & -100000 & 107000 & 7000 & 2 & 2 \\
\hline
\end{tabular}

Langkah selanjutnya adalah menghitung jarak terdekat antara setiap data dan centroid. Agar lebih mudah diambil contoh data pertama pada data percobaan yang dapat dilihat pada tabel 3 .

Tabel 3. Data pertama pada data percobaaan

\begin{tabular}{|c|c|c|c|c|c|}
\hline $\begin{array}{c}\text { Tahun } \\
\text { Angkatan }\end{array}$ & Discount & $\begin{array}{c}\text { Sub } \\
\text { Total }\end{array}$ & $\begin{array}{c}\text { Total } \\
\text { Paid }\end{array}$ & $\begin{array}{c}\text { Total } \\
\text { Item }\end{array}$ & $\begin{array}{c}\text { Tang } \\
\text { gal }\end{array}$ \\
\hline 2013 & -100000 & $\begin{array}{c}10000 \\
0\end{array}$ & 0 & 2 & 2 \\
\hline
\end{tabular}


Dengan menggunakan persamaan euclidean distance space, diperoleh perhitungan jarak sebagai berikut:

$d(c 1)=\sqrt{\begin{array}{c}(2013-2014)^{2}+(-100000--100000)^{2}+(100000-100000)^{2} \\ +(0-0)^{2}+(2-2)^{2}+(2-2)^{2}\end{array}}=18384,77642$ $d(c 2)=\sqrt{\begin{array}{c}(2013-2015)^{2}+(-100000--100000)^{2}+(100000-100000)^{2} \\ +(0-16000)^{2}+(2-2)^{2}+(2-2)^{2}\end{array}}=22627,41709$ $d(c 3)=\sqrt{\begin{array}{c}(2013-2015)^{2}+(-100000--100000)^{2}+(100000-100000)^{2} \\ +(0-7000)^{2}+(2-2)^{2}+(2-2)^{2}\end{array}}=9899,495139$

Jarak terdekat berdasarkan perhitungan diatas adalah jarak pada centroid ketiga, sehingga data tersebut menjadi anggota cluster 3. Demikian seterusnya hingga setiap data selesai dihitung. Selanjutnya tentukan centroid baru dan lakukan langkah diatas sampai diperoleh hasil dengan jarak yang konstan dan anggota cluster tidak mengalami perubahan.

\subsection{Pengujian}

Pengujian menggunakan metode blackbox dilakukan untuk menemukan kesalahan dan ketidaksesuaian fungsi dalam aplikasi, dimana pengujian dilakukan terhadap setiap fungsi yang terdapat pada program. Fokus utama pengujian ini adalah pada spesifikasi fungsional dalam aplikasi. Tabel 4 memperlihatkan hasil pengujian blackbox yang menunjukkan bahwa aplikasi pengelompokan pelanggan telah berjalan dengan baik.

Tabel 4. Hasil pengujian blackbox aplikasi pengelompokan pelanggan

\begin{tabular}{|c|c|c|c|c|}
\hline Fungsi & Skenario & Input & Output & Keterangan \\
\hline Input Data & $\begin{array}{c}\text { Menambahkan data baru kedalam } \\
\text { database }\end{array}$ & $\begin{array}{l}\text { NIM, Discount, Subtotal, } \\
\text { Total Item }\end{array}$ & $\begin{array}{l}\text { Data berhasil ditambahkan } \\
\text { ke database }\end{array}$ & Valid \\
\hline Upload File & $\begin{array}{l}\text { Mengunggah dokumen dengan format } \\
\text { CSV kedalam database }\end{array}$ & Dokumen CSV & Dokumen berhasil diunggah & Valid \\
\hline Hapus Data & $\begin{array}{c}\text { Menghapus yang berada dalam } \\
\text { database }\end{array}$ & Klik Tombol Hapus & Data berhasil dihapus & Valid \\
\hline Edit Data & $\begin{array}{l}\text { Mengedit Data yang berada dalam } \\
\text { database }\end{array}$ & Klik Tombol Edit & Data berhasil di-edit & Valid \\
\hline $\begin{array}{l}\text { Input Proses } \\
\text { K-means }\end{array}$ & $\begin{array}{l}\text { Memasukkan jumlah cluster dan jumlah } \\
\text { iterasi untuk proses clustering }\end{array}$ & $\begin{array}{c}\text { Jumlah cluster dan jumlah } \\
\text { iterasi }\end{array}$ & $\begin{array}{c}\text { Nilai tersimpan dalam } \\
\text { variabel } \mathrm{K} \text { dan Maxruns }\end{array}$ & Valid \\
\hline $\begin{array}{l}\text { Proses K- } \\
\text { means } \\
\text { clustering }\end{array}$ & Mengelompokkan data kedalam cluster & Klik tombol proses. & $\begin{array}{c}\text { Data diproses, } \\
\text { menampilkan centroid } \\
\text { proses. }\end{array}$ & Valid \\
\hline $\begin{array}{l}\text { Lihat Hasil } \\
\text { Cluster }\end{array}$ & $\begin{array}{l}\text { Menampilkan hasil pengelompokan } \\
\text { keseluruhan. }\end{array}$ & $\begin{array}{c}\text { Menekan Tombol Lihat } \\
\text { Hasil Cluster }\end{array}$ & $\begin{array}{l}\text { Dta berhasil ditampilkan } \\
\text { dalam tabel }\end{array}$ & Valid \\
\hline $\begin{array}{l}\text { Lihat Anggota } \\
\text { Cluster }\end{array}$ & Menampilkan hasil untuk setiap cluster. & $\begin{array}{c}\text { Menekan Tombol Anggota } \\
\text { Cluster }\end{array}$ & $\begin{array}{c}\text { Data berhasil ditampilkan } \\
\text { dalam tabel }\end{array}$ & Valid \\
\hline
\end{tabular}

Pengujian kedua adalah untuk membuktikan keakuratan hasil pengelompokan pelanggan dalam aplikasi. Pengujian dilakukan dengan cara membandingkan anggota cluster pengelompokan dari aplikasi dengan hasil yang diperoleh dari software RapidMiner.

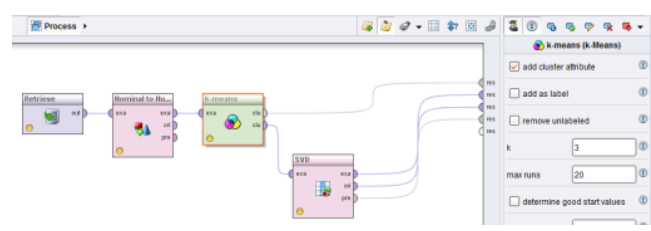

Gambar 9. Tampilan RapidMiner dengan proses $K$-means

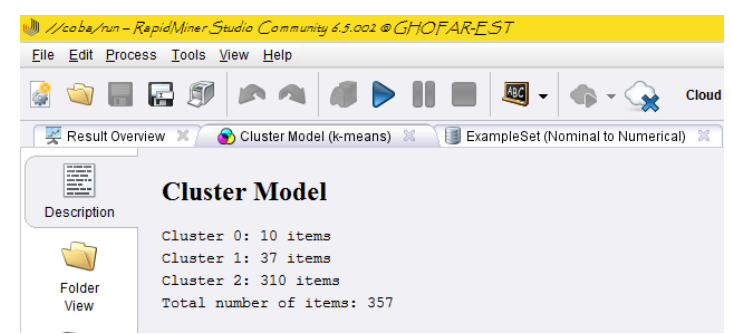

Gambar 10. Tampilan Cluster Model pada RapidMiner

Gambar 9 dan Gambar 10 menunjukkan prroses dan hasil dari pengelompokan menggunakan Software Rapidminer. Berdasarkan hasil pengelompokan pelanggan baik menggunakan aplikasi pengelompokan ini maupun 
software Rapidminer pada akhirnya mendapatkan hasil yang sama.

\subsection{Interpretasi Hasil}

Pada penelitian ini, aplikasi pengelompokan pelanggan menggunakan algoritma $k$-means telah diimplementasikan pada data percobaan dan sesuai dengan yang diharapkan. Berdasarkan sampel sebanyak 357 data, setelah dilakukan pengelompokan dengan jumlah kelompok sebanyak tiga cluster diperoleh hasil sebagai berikut: anggota cluster 1 dengan titik centroid akhir (2013.967; -100000; $101687.741 ; 1687.741 ; 3.351 ; 7.429)$ berjumlah 310 data, cluster 2 dengan titik centroid (2014.270; -100000; $125908.108 ; 25908.108 ; 1.891 ; 8.432)$ berjumlah 37 data dan cluster 3 dengan titik centroid akhir (2014.500; $100000 ; 162390 ; 62390 ; 1.200 ; 6.600)$ berjumlah 10 data. Sehingga dengan membandingkan nilai atribut dalam setiap kelompok dapat diambil kesimpulan bahwa kelompok pelanggan potensial berada dalam cluster 3 . Kelompok inilah yang akan menjadi rekomendasi pada UMS Store.

\section{PENUTUP}

Berdasarkan hasil penelitian yang telah dilakukan dapat diambil beberapa kesimpulan diantaranya:

1. Sistem pengelompokan pelanggan dengan menggunakan algoritma k-means berhasil dibuat untuk mengelompokkan pelanggan potensial.

2. Berdasarkan pengujian Blackbox aplikasi telah berjalan dengan baik. Sedangkan pengujian hasil dengan menggunakan software RapidMiner juga mendapatkan hasil yang sama dengan aplikasi pengelompokan pelanggan.

3. Pengelompokan yang dihasilkan berdasarkan perhitungan jarak terdekat antara setiap data dengan centroid. Jumlah cluster dalam sistem dapat ditentukan sebanyak 3 cluster.

\section{DAFTAR PUSTAKA}

Bahar, A., Pramono, B., \& Sagala, L. H. (2016). Penentuan Strategi Penjualan Alat-Alat Tattoo di
Studio Sonyxtattoo Menggunakan Metode KMeans Clustering. Semantik, 2(2), 75-86.

Ezenkwu, C. P., Ozuomba, S., \& Kalu, C. (2015). Application of K-Means Algorithm for Efficient Customer Segmentation: A Strategy for Targeted Customer Services. IJARAI, 4(10), 40-44. doi:10.14569/IJARAI.2015.041007

Handoko, K. (2016). Penerapan Data Mining dalam Meningkatkan Mutu Pembelajaran pada Instansi Perguruan Tinggi Menggunakan Metode K-Means Clustering (Studi Kasus di Program Studi TKJ Akademi Komunitas Solok Selatan). TEKNOSI, 02(3), 31-40. doi:https://doi.org/10.25077/TEKNOSI.v2i3.2016.3 $1-40$

Jain, N., \& Ahuja, V. (2014). Segmenting Online Consumers Using K-means Cluster Analysis. International Journal of Logistics Economics and Globalisation, $\quad 6(2), \quad 161-178$. doi:https://doi.org/10.1504/IJLEG.2014.068274

Khandre, A., \& Alvi, A. S. (2016). Efficient Clustering Algorithm with Improved Clusters Quality. IOSRJCE, 18(6), 15-19. doi:10.9790/0661-1806051519

Kurniawan, Y. I., \& Windisani, P. A. (2017). Sistem Pendukung Keputusan untuk Penentuan Kelolosan Beasiswa Sekolah Menengah Kejuruan (SMK) Menggunakan Metode Fuzzy . Jurnal Teknik Elektro, 9(1).

Lanjewar, R., \& Yadav, O. P. (2013). Understanding of Customer Profiling and Segmentation Using KMeans Clustering Method for Raipur Sahkari Dugdh Sangh Milk Products. IJRCCT, 2(3), 103107.

Nugroho, Y. S., \& Haryati, S. N. (2015). Klasifikasi dan Klastering Penjurusan SMA Negeri 3 Boyolali. Khazanah Informatika, 1(1), 1-6. doi:https://doi.org/10.23917/khif.v1i1.1175

Prabiantissa, C. N., Ririd, A. R., \& Asmara, R. A. (2017). Sistem Identifikasi Batik Alami dan Batik Sintetis Berdasarkan Karakteristik Warna Citra dengan Metode K-Means Clustering. Jurnal Informatika Polinema, 5(2), 26-31.

Sumadikarta, I., \& Abeiza, E. (2016). Penerapan Algoritma K=Means pada Data Mining Untuk Memilih Produk dan Pelanggan Potensial (Studi Kasus : PT Mega Arvia Utama). Jurnal Satya Informatika, 1(1), 12-22.

Tikmani, J., Tiwari, S., \& Khedkar, S. (2015). An Approach To Consumer Classification Using KMeans. IJIRCCE, 3(11), 10542-10549. doi:10.15680/IJIRCCE.2015.0311029 